\title{
Determinación de la responsabilidad civil por el manejo de recursos públicos en la Administración
}

\author{
Determination of civil liability for the management of public resources \\ in the Administration
}

\author{
Ángela Cerda Cattan
}

Abogada, Universidad Central de Chile

\begin{abstract}
RESUMEN La investigación analiza algunos aspectos relevantes de la responsabilidad civil por el manejo o cuidado de recursos públicos en la Administración a partir de sus rasgos generales, y luego desde sus elementos específicos, y de las normas particulares del proceso encaminado a su establecimiento. Asimismo, intenta esclarecer el rol que desempeña la contravención de un deber vinculado al ejercicio de la función pública, como un elemento fundante de la responsabilidad del agente.
\end{abstract}

PALABRAS CLAVE Responsabilidad civil, administración de recursos públicos, deberes de la función pública.

ABSTRACT The research analyzes some important aspects of the civil liability for the management of public resources by the Public Administration, from its general features to its specific elements and the particular rules of the judicial process intended to determine it. The study also attempts to clarify the role played by the breach of a duty prescribed by applicable law, regulation or administrative provision, as a fundamental element of such liability.

KEYWORDS Civil liability, public resources management, public service.

\section{Antecedentes generales}

En Chile el legislador no ha entregado una definición de Administración del Estado. Sin embargo, el artículo 1 de la Ley 18.575 de Bases Generales de la Administración del Estado enumera los órganos que la integran, al igual que el artículo 2 de la Ley 19.880 
de Bases de los Procedimientos Administrativos que rigen los Actos de los Órganos de la Administración. Dichas normas comprenden a todos los órganos y servicios públicos creados especialmente para el cumplimiento de la función administrativa del Estado, por lo que resultan excluidos otros órganos como el poder judicial y los órganos legislativos, así como las organizaciones privadas que realicen actividades de administración accesoria (Pallavicini, 2012: 2-66).

La Administración se estructura sobre la base de ciertos principios que informan la función pública ${ }^{1}$ y que se sustentan en el texto constitucional chileno. ${ }^{2}$ Uno de los principios fundamentales es el de responsabilidad, el cual envuelve tanto la denominada responsabilidad orgánica de los entes públicos administrativos como la de los sujetos que sirven a los órganos del Estado (Caldera, 1991: 217), y que puede a su vez tener una naturaleza civil, administrativa, penal y política.

Estas responsabilidades a que puede dar lugar la actuación de los sujetos que sirven en la Administración obedecen a diversas fundamentaciones, circunstancias, finalidades y, además, poseen una configuración jurídica propia (Aldunate, 2009: 117). De ahí que la responsabilidad administrativa es independiente de la responsabilidad civil y penal a que pudieran conducir los mismos hechos. ${ }^{3}$

En particular, la responsabilidad administrativa se origina en el incumplimiento de deberes específicos de ciertas personas en su calidad de funcionarios o integrantes de instituciones de la Administración, manifestados en una obligación, prohibición o incompatibilidad funcionaria (Montero, 2015b: 134). Ella se regula principalmente por la Ley 18.575 y por el Estatuto Administrativo para funcionarios públicos o municipales, según sea el caso, y se determina previo sumario administrativo o investigación sumaria que culminará en el sobreseimiento, la absolución, o en la aplicación de alguna medida disciplinaria, esto es, censura, multa, suspensión o destitución.

La responsabilidad penal se configura, desde luego, solo si la conducta está tipificada como un delito para los servidores públicos, que puedan cometer en el ejercicio de sus funciones, y es sancionado con una pena privativa o restrictiva de la libertad, priva-

1. La función pública ha sido entendida como aquella actividad que incluye la práctica de cualquiera de las competencias que el ordenamiento jurídico ha conferido a cada uno de los poderes del Estado y a los órganos que participan en la ejecución de sus potestades (Caldera, 1991: 219).

2. Específicamente en los artículos 6, 7 y 8 de la Constitución Política de la República, que establecen los principios de juridicidad, responsabilidad y probidad. Esos principios también se encuentran contenidos y desarrollados en la Ley 18.575, que en su artículo 3 inciso segundo prescribe que la Administración del Estado deberá observar, entre otros, los principios de responsabilidad, eficiencia, eficacia, control, probidad, transparencia y publicidad administrativas.

3. Los artículos 120 y 119 de las Leyes 18.834 y 18.883 sobre Estatuto Administrativo para funcionarios públicos y para funcionarios municipales, respectivamente, consagran la independencia de las responsabilidades. No obstante, esos preceptos ordenan la reincorporación a la institución del funcionario destituido como consecuencia exclusiva de hechos que revisten caracteres de delito, si en el proceso criminal hubiere sido absuelto o sobreseído definitivamente por no constituir delito tales hechos. En los demás casos de sobreseimiento definitivo o sentencia absolutoria, disponen que podrá pedirse la reapertura del sumario administrativo, y si en este se absolviere al funcionario, corresponderá también la reincorporación. 
tiva de derechos y, también, pecuniaria, la que se hace efectiva a través de los procesos contemplados por el legislador penal (Celis, 2010: 884).

Confinada a determinadas autoridades políticas o administrativas que específicamente señala la Constitución, queda la responsabilidad política cuando aquellas incurren en los actos (acciones u omisiones) que se contemplan respecto de cada una en la referida Carta Fundamental, como la responsabilidad del presidente y de sus ministros, establecida en su artículo 52 numeral 2 letras a) y b), que se determina mediante un juicio político.

Finalmente, puede surgir la responsabilidad civil por el daño que ocasiona un servidor de la Administración, y que se traduce en la imposición del deber de reparar el detrimento causado al patrimonio público.

Ahora bien, cuando el perjuicio que sufre el Estado es ocasionado por una mala administración de los recursos públicos por parte del funcionario a quien han sido confiados, deben considerarse algunas características particulares que concurren en esta responsabilidad patrimonial para los efectos de configurarla, que revisamos a continuación.

Cabe precisar en primer término que en Chile, a diferencia de lo que sucede en otros ordenamientos jurídicos (como por ejemplo los de Colombia, ${ }^{4}$ Argentina ${ }^{5}$ o España ${ }^{6}$ ) esta responsabilidad patrimonial de los servidores públicos ha sido asimilada a la responsabilidad civil extracontractual, tanto por la doctrina como por la jurisprudencia uniforme del Tribunal de Cuentas (Jara, 2012: 138).

La cuestión, aunque ligeramente, ha sido abordada a propósito del juicio de cuentas (Hanssen, 2007: 47). Pero ya en el año 1981 Caldera (103) admitía que estábamos en presencia de un tipo de responsabilidad civil no contractual, que no quedaba integralmente regulada por las reglas de la responsabilidad extracontractual ordinaria o clásica. Ello precisamente por presentar algunas peculiaridades frente a esta.

En efecto, en este régimen se aprecia la existencia de un vínculo jurídico entre el Estado y el servidor, anterior al nacimiento de la obligación de reparar, presupuesto que

4. En Colombia se habla de responsabilidad fiscal como aquella que les asiste a los funcionarios que administran, custodian o recaudan bienes o dineros oficiales, y que tienen la labor de rendir cuentas y reintegrar lo que en su contra resulte, afirmándose que se trata de una responsabilidad administrativa cuyo objeto son únicamente los dineros oficiales que se reciben para su custodia, manejo o administración (Ossa, 2009: 52).

5. La responsabilidad patrimonial de los funcionarios públicos se identifica en Argentina con la función de control externo y se determina en sede judicial, pero se encuentra sometida a un régimen administrativo particular previo a la iniciación de acciones judiciales en que se deslindan las responsabilidades, se fija el quantum del perjuicio fiscal y se intima a su pago (Ivanega, 2000: 601-610).

6. El sistema español caracteriza a esta responsabilidad como una institución de derecho público, de carácter patrimonial, referida solo a los fondos, que lleva en sí misma la infracción de normas de naturaleza contable y presupuestaria, y parte del supuesto de la existencia de una relación jurídica entre la Administración titular de los fondos y la persona a la que le son entregados estos para su gestión, denominada relación jurídico-contable. (Cortell, 2000: 106; González, 2014: 71). 
es más bien propio de las obligaciones contractuales. Empero, esa relación no surge a partir del acuerdo de voluntades, sino que es impuesta por el Estado unilateralmente (Abeliuk, 2014: 354) y nace a través del nombramiento o de la resolución que aprueba el respectivo contrato.

Una vez constituida la relación, los deberes del sujeto que se desempeña en la Administración se precisan en diferentes cuerpos normativos, que a diferencia de lo que sucede en el ámbito privado, son indisponibles para las partes (Severo, 1991: 366). Su reglamentación principal es el Estatuto Administrativo contenido en la Ley 18.834, ${ }^{7}$ que comprende el régimen de derecho integral de quienes se desempeñan para los órganos de la administración pública y que regula el ingreso, los deberes y derechos, la responsabilidad administrativa y la cesación de funciones (artículos 15 y 17 de la Ley 18.575).

De esta forma, las obligaciones que emanan del vínculo entre el Estado y el servidor público no son de origen contractual, sino que legal y/o reglamentario. Por consiguiente, como los servidores que administran efectos públicos no se encuentran sometidos a las disposiciones que rigen los contratos, ${ }^{8}$ su obligación de reparar al Estado por los daños ocasionados en esa administración tampoco es de naturaleza contractual.

Entonces, la responsabilidad civil por el manejo de bienes y fondos públicos, a pesar del vínculo jurídico previo entre víctima y victimario, se adecua mejor al estatuto extracontractual, pues en doctrina nacional, siguiendo la legislación civil, se considera responsabilidad extracontractual aquella que no tiene su origen en un contrato (Rodríguez, 1999: 20; Aedo, 2006: 31; Ducci, 1970: 11; Alessandri, 2005: 34; Barros, 2006: 18-22). Cosa distinta es que no pueda desatenderse la existencia de tal vínculo, así como sus consecuencias, pues incidirá en estas.

En segundo lugar, esta responsabilidad persigue fundamentalmente la indemnidad patrimonial del Estado como sujeto afectado mediante el resarcimiento de los daños que le fueran irrogados. En este sentido, no tendría sino la misma función reparadora que caracteriza esencialmente a la responsabilidad civil en general.

Sin embargo, esta responsabilidad en el ámbito que tratamos presenta conjunta y necesariamente otras funciones. Así, se considera que cumple una función punitiva, al ser percibida la obligación de reparar como una sanción por el agente. Igualmente, una función preventiva y de control del ejercicio de la función pública, pues orienta los comportamientos hacia un mayor cuidado y diligencia. En este orden, si existe un pronunciamiento judicial que estime como indebido o ilegal cierto uso de recursos públicos, con el consecuente detrimento patrimonial para el Estado, ello servirá para

7. El artículo 1 del aludido cuerpo legal dispone: «Las relaciones entre el Estado y el personal de los Ministerios, Intendencias, Gobernaciones y de los servicios públicos centralizados y descentralizados creados para el cumplimiento de la función administrativa, se regularán por las normas del presente Estatuto Administrativo, con las excepciones que establece el inciso segundo del artículo 21 de la Ley 18.575». Lo propio ocurre con los servidores de las corporaciones edilicias, que se encuentran afectos al Estatuto Administrativo para funcionarios municipales.

8. La jurisprudencia administrativa del Órgano Superior de Control se ha pronunciado en esa dirección en los Dictámenes de la Contraloría General de la República 67.095, 1975; 8.415 y 8.419, 1983 y 15.412, 1984. 
que en el futuro los otros agentes administradores se abstengan de darles el mismo uso a dichos recursos. ${ }^{9}$

A lo señalado se suma que, en la etapa previa a la judicialización del asunto, muchas normas sobre gastos deben ser interpretadas para aplicarlas a los casos concretos, labor que realiza la Contraloría General de la República a través de jurisprudencia vinculante para los órganos de la Administración (inciso final del artículo 6 de la Ley 10.336 Orgánica de la Contraloría General de la República, que se remite a los asuntos señalados en su artículo 1), pero cuyos criterios no son necesariamente estables.

De manera que antes de realizar un acto referido a la administración o disposición de bienes o fondos públicos, las reparticiones públicas deben verificar la procedencia del mismo, en la normativa específica, como también en la jurisprudencia administrativa y jurisdiccional de cuentas.

Una tercera particularidad de este régimen de responsabilidad dice relación con el objeto protegido y la forma a través de la cual se causa el perjuicio. En cuanto a lo primero, es evidente que este se produce respecto de recursos públicos comprendidos en el patrimonio de todas las personas jurídicas administrativas de derecho público, entre los cuales que se cuentan bienes fiscales y municipales. ${ }^{10}$

En cuanto a la forma, ciertamente esta lesión que experimenta el Estado es de carácter patrimonial, ${ }^{11}$ traduciéndose principalmente en un daño emergente, ${ }^{12}$ esto es, en

9. Sirvan de ejemplo aquellos desembolsos realizados por entidades edilicias que no pueden atribuirse a actividades municipales, como los gastos efectuados con ocasión de la celebración del día de la madre o del padre, o bien, determinados gastos en publicidad considerados innecesarios para el cumplimiento de sus funciones, los que han sido considerados como perjudiciales para el patrimonio del Estado por la jurisprudencia de cuentas a partir del año 2008. (Véase Tribunal de Cuentas de segunda instancia, sentencia rol 1-07, «Contraloría General de la República con Velásquez, Pedro», 8 de julio de 2008; sentencia rol 33.944-08, "Contraloría General de la República con Pérez, Francisco», 27 de enero de 2010; sentencia rol 36.324-09, "Contraloría General de la República con Sepúlveda, Débora», 8 de marzo de 2011; sentencia rol 45.188-12, «Contraloría General de la República con Velásquez, Elda», 5 de marzo de 2015; sentencia rol 119-2013, «Contraloría General de la República con Cicardini, Maglio», 3 de febrero de 2017 y sentencia rol 185-2015, «Contraloría General de la República con San Román, Fernando», 24 de julio de 2017).

10. Los recursos fiscales provienen de la persona jurídica Fisco y financian a los servicios dependientes o centralizados, en tanto los recursos municipales se originan en los ingresos ordinarios de las corporaciones edilicias denominados rentas municipales, como también de sus aportes extraordinarios (Contraloría General de la República, 1986: 12).

11. Si bien el daño puede ser moral o material, en doctrina se ha señalado que a pesar de que el daño moral del Estado se confunde con el interés social, ello no es óbice para para vedarle que accione por daño moral, dado que en definitiva el daño material también se confunde con el interés social (Bidart, 1985: 118). Este tópico no se abordará en atención a que escapa del marco de la presente investigación en que el daño se limita al menoscabo puramente patrimonial del Estado.

12. No obstante, el Tribunal de Cuentas de segunda instancia en la sentencia rol 32.278-07, «Contraloría General de la República con Castro, Walton», 10 de mayo de 2010, ordenó resarcir el lucro cesante, o la utilidad o beneficio económico que ordinaria y razonablemente habría percibido el Estado de no haber mediado el hecho nocivo, en el caso del funcionario que no cobró debidamente una multa en favor del Estado impuesta por alguna convención, la cual se miraba como una ganancia que el ente público dejó de percibir. 
un detrimento patrimonial efectivamente sufrido por el ente estatal. Para esto se debe determinar la diferencia que se produjo en el activo del patrimonio respectivo, entre la situación anterior al hecho que se reprocha y después del mismo (Rodríguez, 1999: 291; Peirano, 1979: 361).

En tal sentido, la jurisprudencia del Tribunal de Cuentas de segunda instancia ha sostenido que no basta la simple lesión del interés público derivada de infracciones a las normas sobre gasto público para establecer la existencia del daño, sino que es indispensable que aquel perjuicio se traduzca en una merma concreta en el patrimonio afectado por el acto ilícito. ${ }^{13}$

Pero bien puede ocurrir que alguna repartición pública realice un desembolso que pugne con la legalidad del gasto público, y además produzca disminución patrimonial efectiva, no obstante lo cual, tal egreso no se juzgue como perjudicial para el Estado.

Tal es el caso, por ejemplo, de una modificación de una obra pública que no estaba contemplada en ningún instrumento legal, reglamentario o contractual, y que tiene como consecuencia para el ente estatal asumir un costo final más alto del primitivamente acordado. Se observa que el egreso verificado produce una disminución del activo patrimonial del órgano público respectivo al realizar un desembolso mayor al proyectado, en contravención al principio de legalidad del gasto. Empero, dicha modificación puede responder a una necesidad de mejorar la prestación del servicio que se tuvo en vista al momento de contratar la obra, o bien, aumentar la durabilidad de las instalaciones.

$\mathrm{Al}$ respecto, Ferrada (2012: 313) plantea que si de las acciones consideradas ilegales y que importan un gasto público existe un beneficio para el propio patrimonio público, no se configura el daño patrimonial ni la subsecuente responsabilidad del sujeto imputado que lo obligue a la reparación.

De esta forma, para el mencionado autor el beneficio para el patrimonio público es un factor que contrarresta los efectos lesivos del egreso ilegal y obsta a la conformación del daño.

Ciertamente, un beneficio cuantificable económicamente tiene la aptitud para compensar una merma de activos y así impedir la construcción del daño material como elemento de la responsabilidad en examen. Pero aquellos beneficios no avaluables en dinero, como el hecho de que la nueva obra permitirá a los usuarios sentirse más satisfechos con la prestación del servicio de que se trate, han de ser analizados en torno a otros elementos, como la imputabilidad del agente, ya que el perjuicio patrimonial no resulta preliminarmente disminuido por concurrir tales provechos.

Pareciera ser entonces que para dar por establecido el daño como elemento central de la responsabilidad en estudio, deben analizarse otras circunstancias que pueden paliar la lesión material concreta.

13. Tribunal de Cuentas de segunda instancia, sentencia rol 3-2013, «Contraloría General de la República con Tatter, Jorge», 12 de agosto de 2016; sentencia rol 80-2014, "Contraloría General de la República con Cuvertino, Luis», 30 de enero de 2017 y sentencia rol 6-2013, "Contraloría General de la República con Venegas, Nelson», 27 de marzo de 2017. 
Finalmente, corresponde indicar que los sujetos involucrados en la relación son, por una parte, el Estado afectado en su patrimonio, y por la otra, el sujeto que ocasiona el perjuicio, esto es, un agente o funcionario en el desempeño de su cargo. Por ello se ha dicho que se trata de un daño interorgánico (Caldera, 1981: 101), ${ }^{14}$ sin embargo, al momento de analizar la conducta lesiva del sujeto, aquella no necesariamente importa un actuar inescindible del órgano al que sirve.

Pues bien, el sujeto que maneja recursos públicos es un ejecutor de la voluntad del órgano estatal para el cumplimiento de los fines establecidos en la carta fundamental y demás leyes que regulan la repartición a la que pertenece, en virtud de una relación de derecho público, la cual puede ser de diversa naturaleza según el Estatuto Administrativo.

En efecto, entre las personas que desempeñan sus funciones en la Administración se pueden distinguir aquellos que ejercen un cargo público, los contratados bajo el régimen establecido por el Código del Trabajo, y aquellos sujetos contratados a honorarios.

Las personas que ejercen un cargo público son aquellas que se contemplan en las plantas o como empleos a contrata a través de los cuales se realiza una función administrativa, y se denominan funcionarios públicos. ${ }^{15}$

Los contratados por el Código del Trabajo estarán sujetos al Estatuto Administrativo en la medida en que ello se contemple explícitamente en su contrato, ${ }^{16}$ circunstancia que supone el reconocimiento de ciertos servidores que, en tanto forman parte de los órganos de la Administración, pueden poseer atribuciones de administración de presupuestos, o de tenencia y custodia de bienes públicos. ${ }^{17}$

Por último, según lo dispone el artículo 11 del mencionado estatuto, se contrata a honorarios mediante resolución de la autoridad correspondiente, a profesionales y técnicos de educación superior o expertos en determinadas materias que realizan labores accidentales de la institución.

Estos se rigen por el respectivo contrato, no les son aplicables las disposiciones del Estatuto, no revisten la calidad de funcionarios públicos y no pueden ejercer cargos

\footnotetext{
14. En el mismo sentido se ha pronunciado la Corte de Apelaciones de Santiago, sentencia rol 1925-92, 23 de diciembre de 1993 .

15. Según los artículos 3, 4 y 5 de la Ley 18.834, el personal de planta ocupa cargos permanentes asignados por la ley a cada institución. El empleo a contrata es de carácter transitorio por cuanto dura como máximo hasta el 31 de diciembre de cada año, y de acuerdo a la jurisprudencia administrativa que ha interpretado los artículos 6, 7 y 8 del mencionado estatuto, estos no pueden desempeñar cargos de jefatura o labores resolutivas inherentes a las funciones de jefatura. Dictamen de la Contraloría General de la República 21.719, 1991.

16. El Dictamen de la Contraloría General de la República 14.621, 2017, señala que el contrato debe ajustarse al carácter de público de la parte que requiere los servicios, lo que obliga a la autoridad a respetar los principios que rigen su accionar. Así también los Dictámenes de la Contraloría General de la República 5.628, 2007; 7.604, 2003 y 47.967, 2000.

17. Tribunal de Cuentas de segunda instancia, sentencia rol 33.064-08, «Contraloría General de la República con Bravo, Eva», 17 de marzo de 2010.
} 
de jefatura, todo lo cual se traduce en que no se encuentran afectos a responsabilidad administrativa o patrimonial (Aldunate, 2009: 14-16). De hecho, entre sus funciones no se cuenta, en principio, custodiar o administrar bienes públicos.

De este modo, aunque todos los individuos señalados pueden eventualmente tener responsabilidad ante el Estado, son fundamentalmente aquellos que se rigen por las normas del Estatuto Administrativo a quienes se les confía el cuidado y administración de bienes públicos; es decir, aquellos individuos vinculados a la Administración como funcionarios de planta y a contrata, y cuando la vinculación estatutaria viene dada por el Código del Trabajo en ciertos supuestos contemplados por el instrumento contractual.

En síntesis, a pesar de que la responsabilidad patrimonial por el manejo de bienes públicos se encuentra asimilada en Chile al régimen de responsabilidad civil extracontractual, resulta evidente que esta presenta algunos rasgos particulares, entre los que se cuentan la existencia de un vínculo jurídico previo entre los sujetos involucrados, las calidades de los mismos, la relevancia de las funciones punitiva y preventiva concurrentes a la reparatoria, y el objeto protegido.

\section{Atribución de responsabilidad por la administración o custodia de bienes o fondos públicos}

La conducta generadora del perjuicio para el patrimonio público puede ser una acción o una omisión como, por ejemplo, un pago por un servicio no prestado o por una obra no ejecutada en su totalidad, un gasto al margen de la legalidad o un retardo en el pago de obligaciones periódicas del servicio. Mas, para que surja la responsabilidad civil, dicha conducta debe ser imputable al autor.

Esta imputabilidad hace posible referir un acto cualquiera a la actividad de una persona (Peirano, 1979: 21). Permite, como presupuesto de la responsabilidad, atribuir un daño al sujeto que se vincule causalmente a él o, dicho de otro modo, importa determinar quién soporta los efectos de ese daño.

Para que tenga lugar esa atribución, el hecho nocivo debe encontrarse comprendido en alguno de los supuestos normativos de responsabilidad, que prevén criterios de imputación (Wollcott, 2002: 79). Estos criterios, de acuerdo con las reglas generales del Código Civil, corresponden al dolo o la culpa.

\section{Responsabilidad por dolo o culpa}

El dolo, de acuerdo al artículo 44 inciso final del Código Civil, es la intención positiva de inferir injuria en la persona o propiedad de otro.

En torno a este elemento se presentan dos tendencias relevantes en doctrina, que colisionan tanto en la determinación del hecho que sirve de base para establecer el dolo como en la relación de la experiencia interna del sujeto con los hechos (Chadwick, 2009b: 380). 
En efecto, la posición que siguen las doctrinas nacidas en el derecho penal alemán, extendidas por el autor de origen austriaco Frank von Lizst, ha entendido el dolo en una concepción más laxa, que incluye además del dolo directo, el dolo eventual (Banfi, 2015: 800), con los elementos de previsibilidad del resultado dañoso y aceptación del mismo, de manera que para que exista intencionalidad, basta con la conciencia de su posible ocurrencia por parte del agente (Rodríguez, 1999: 165; Corral, 2013: 205).

La otra tendencia sostiene que no resulta suficiente solo prever, sino que se hace necesaria la voluntad de causar daño (Mazeaud, Mazeaud y Tunc, 1962: 52-66), por lo que el dolo posee contornos precisos, establecidos en el aludido artículo 44, que lo define como una intención, razón por la cual esta postura estima que una concepción más amplia de dolo no tendría acogida en el sistema chileno de responsabilidad (Alessandri, 2005: 120; Meza, 1997: 262; Chadwick 2009a: 377).

En todo caso, el juez apreciará la concurrencia de dolo en concreto, esto quiere decir que realizará un examen de las circunstancias personales concretas del sujeto para desentrañar su intencionalidad de actuar ilícitamente (Corral, 2013:300).

El dolo no tiene un efecto distinto de la culpa conforme a las reglas generales del derecho civil, pero en materia de manejo o administración de recursos públicos, cuando concurre dolo en la conducta del sujeto se configurará normalmente un ilícito penal especial, dada la calidad de este como administrador de efectos públicos; y, establecido que sea el delito, se dará lugar a los elementos de la responsabilidad extracontractual como una consecuencia necesaria de aquel. ${ }^{18}$

Esos delitos exigen dolo directo, que de acuerdo con la doctrina penal chilena implica que el hecho típico es el objetivo que el hechor quiere lograr, de modo que la intención del sujeto coincide con el resultado de la acción realizada. Tal modalidad del dolo excluye al dolo eventual, que solo requiere la representación del resultado, no el propósito de producirlo (Politoff y otros, 2004: 275; Garrido, 2005: 101-103).

De ahí que la asunción de una interpretación laxa del dolo impide configurar una conducta sancionable penalmente, pero no obsta a la comisión de un delito civil del cual surge la obligación de indemnizar a la víctima.

En cuanto al elemento culpa, el Código Civil chileno no contiene una definición general, sino que distingue tres clases o estándares de culpa en el artículo 44.

Ante la falta de definición legal, la doctrina nacional ha elaborado diversas nociones de culpa como un error de conducta o una infracción a un deber de conducta, siguiendo con algunos matices a Mazeaud, Mazeaud y Tunc (1962: 78-85), quienes definieron

18. Rodríguez y Ossandón (2011: 386-441) describen cinco figuras delictivas del Código Penal calificadas como malversación, las que se estructuran sobre la base de la calidad de funcionario público del sujeto que ejecuta la conducta, el carácter público del objeto del delito y la existencia de una especial relación entre el sujeto y el objeto. Ellas son la malversación por apropiación o peculado (artículo 233, modalidad dolosa, y artículo 234, supuesto culposo), malversación por distracción o desfalco (artículo 235), malversación por aplicación pública diferente (artículo 236) y negativa a un pago o entrega (artículo 237). Asimismo, se regulan otras figuras como fraude al Fisco (artículo 239), negociaciones incompatibles (artículo 240), tráfico de influencias (artículo 240 bis), exacciones ilegales (artículo 241) y enriquecimiento ilícito (artículo 241 bis). 
la culpa cuasidelictual como un error de conducta que deriva de un deber general de comportamiento preexistente, y que no lo habría cometido una persona cuidadosa situada en las mismas circunstancias externas que el autor del daño.

En este contexto, Rodríguez entiende que la culpa extracontractual supone «faltar el deber de cuidado que toda persona, por disponerlo la ley o los estándares generales y comunes admitidos por la sociedad, debe emplear para evitar causar un daño que no se habría producido en caso de haberse respetado dicho deber de cuidado y diligencia» (1999: 165).

Por su parte, Barros (2006: 78) caracteriza la culpa como la inobservancia del cuidado debido en la conducta susceptible de dañar a otro, mientras que autores como Ramón Meza (1997: 263) y Arturo Alessandri, presentan una definición que arranca del texto del artículo 44 del Código Civil. Señala el último que la culpa «es la falta de aquella diligencia o cuidado que los hombres prudentes emplean ordinariamente en sus actos y negocios propios» (2005: 126).

Así las cosas, conforme a la noción de la doctrina mayoritaria, una persona incurre en culpa cuando yerra en la conducta debida o bien infringe un deber de diligencia exigible.

Cuestión distinta son las fuentes de las conductas o diligencia debidas. El criterio general para su determinación, por influencia de la doctrina de los Mazeaud, ha sido comparar la conducta ejecutada por el agente con la conducta que habría realizado otro sujeto (un modelo) colocado en las mismas circunstancias. Si el resultado es una coincidencia en el actuar, la conclusión es que el agente actuó como se debía. Si, en cambio, hay una diferencia y esta es negativa, la conclusión es que el agente no actuó como debía, incurriendo en culpa.

En este contexto, habrá de considerar que, si bien el Código Civil chileno contempla tres tipos o grados de culpa en su artículo 44, en realidad comprende tres modelos distintos de conducta con los cuales comparar la actuación del agente: el de las personas negligentes y de poca prudencia, el del hombre medio y el del hombre juicioso. La mayoría de la doctrina entiende aplicables dichos modelos en materia extracontractual, tanto por contenerse el artículo 44 en el título preliminar del Código como por la referencia y aplicación expresa que el inciso primero del artículo 2.323 del mismo cuerpo legal hace del buen padre de familia. ${ }^{19}$

Luego, si la gradación y, por tanto, los modelos de conducta son aplicables en general a la responsabilidad civil por delitos y cuasidelitos, surge la pregunta acerca de si hay un grado en particular aplicable a esta.

Parte de la doctrina nacional se ha inclinado por entender que el grado de culpa en materia de responsabilidad civil extracontractual es la culpa leve, ya que el Código Civil dispone que culpa o descuido, sin otra calificación, significa culpa o descuido leve. Es decir, la regla general sería exigir la diligencia y cuidado que los hombres emplean or-

19. El mentado precepto utiliza ese modelo cuando responsabiliza ante terceros al dueño de un edificio por los daños que ocasione su ruina acaecida por haber omitido las necesarias reparaciones, o por haber faltado de otra manera al cuidado de un buen padre de familia. 
dinariamente en sus negocios propios (Alessandri, 2005: 126; Meza, 1997: 263). Aunque también se ha aseverado que, a falta de distinción, en principio cualquier tipo de culpa dará lugar a la responsabilidad y corresponderá al juez determinar si el descuido es suficiente para constituir culpa (Abeliuk, 2014: 259).

Con todo, a efectos de configurar una culpa en términos objetivos y separada de las consideraciones individuales, o sea, como una deformación del comportamiento del agente respecto de parámetros determinados (Wollcott, 2002: 90-91), es necesario realizar una apreciación in abstracto, es decir, comparativa de la conducta del sujeto con lo que habría observado un hombre prudente promedio de la actividad en la que se desempeñó el agente para causar daño (Corral, 2013: 55). ${ }^{20}$

En la materia, el Tribunal de Cuentas ha exigido un cuidado medio al sujeto que tiene a su cargo fondos o bienes públicos, manifestando la necesidad de pretender aquello que razonable y naturalmente se está obligado a cumplir, lo que importa la exigencia de niveles medios de diligencia. ${ }^{21}$

Hay que mencionar además que el modelo del hombre medio o del buen padre de familia, según Rosso (2002: 3-52), envuelve obligaciones previas consustanciales a la administración de negocios ajenos, ${ }^{22}$ como también ocurre con el manejo de bienes o fondos públicos, dado que el agente siempre se encuentra sujeto a una obligación preexistente, pero no en virtud de una convención, sino de una norma legal o reglamentaria que rige su conducta y que le impone líneas de actuación.

En efecto, la actuación del agente tiene lugar en el ejercicio de la función pública, que ha de desplegarse con arreglo a determinados principios e impone el cumplimiento de variados deberes y obligaciones, como también establece diversas prohibiciones funcionarias, de forma tal que la infracción de la normativa que rige la actuación del individuo cumple una determinada función en el establecimiento de su responsabilidad, como a continuación se expondrá.

\section{La infracción normativa como presupuesto de la responsabilidad en análisis}

En primer término, cabe indicar que el legislador nacional no ha establecido en forma general que este tipo de responsabilidad se derive de la vulneración de un deber admi-

20. Como bien señala Aedo (2006: 208-218), el estándar del buen padre de familia como modelo para la apreciación en abstracto es aceptado unánimemente tanto en Chile como en España, Portugal y Francia, pero tal modelo abstracto pierde asidero al momento de analizar el caso concreto, en que se despliega la función judicial en la apreciación de la conducta.

21. A modo ejemplar, Tribunal de Cuentas de segunda instancia, sentencia rol 38.173-10, "Contraloría General de la República con Meriño, Iván», 16 de mayo de 2014; sentencia rol 41.219-11, "Contraloría General de la República con Lapierre, Alfredo», 6 de abril de 2015; sentencia rol 134-13, "Contraloría General de la República con Araya, Carlos», 2 de marzo de 2015 y sentencia rol 63-13, "Contraloría General de la República con Cortez, Mauricio», 15 de julio de 2015.

22. Es por ese motivo que el aludido autor excluye tal estándar de la responsabilidad extracontractual en que no hay obligación previa. 
nistrativo, pero ello se puede desprender de algunas normas que ordenan la conducta del agente administrador de bienes y fondos públicos.

En concreto, se observan disposiciones aisladas que sugieren la idea de la responsabilidad patrimonial por infracción normativa, tales como los artículos 95 de la Ley 18.834 y 94 de la Ley 18.883 , que prescriben que «las remuneraciones son embargables hasta en un cincuenta por ciento, por resolución judicial ejecutoriada dictada en juicio de alimentos o a requerimiento del Fisco o de la institución a que pertenezca el funcionario, para hacer efectiva la responsabilidad civil proveniente de los actos realizados por este en contravención a sus obligaciones funcionarias». Por su parte, el artículo 42 de la Ley 10.336 que establece la función del Departamento de Crédito Público y Bienes Nacionales del Órgano de Control, entre ellas la letra n), de «proponer las medidas necesarias para hacer efectiva la responsabilidad de los funcionarios a cuyo cargo se encuentren los bienes fiscales por la infracción de cualquiera de las disposiciones en vigencia sobre la materia».

Asimismo, cabe examinar la reglamentación y la jurisprudencia referidas al juicio de cuentas, que es un procedimiento contencioso a través del cual se persigue la responsabilidad pecuniaria de quienes intervienen en la administración, recaudación, custodia e inversión de los fondos o bienes sometidos a la fiscalización de la Contraloría General de la República (Verdugo, 2006: 228).

En ese orden, la jurisprudencia del Tribunal de Cuentas se ha pronunciado en el sentido de construir la responsabilidad a partir de la infracción legal en diversos fallos. ${ }^{23}$ Más aún, ha expresado que el ejercicio malicioso o descuidado de las descripciones legales y reglamentarias de los respectivos cargos, da origen al daño que se demanda. ${ }^{24}$ Así, la vulneración del deber de conducta contenido en la norma administrativa se presenta como un elemento que concurre en la configuración de la responsabilidad pecuniaria.

Igualmente, en la regulación del juicio de cuentas, la existencia de una infracción de la normativa, considerada como un elemento de este tipo de responsabilidad, puede incluso darle sentido a la regla contenida en el artículo 116 de la Ley 10.336, que preceptúa que cuando por la naturaleza de los hechos investigados en el juicio no procediere condenar pecuniariamente al cuentadante, el juez de primera instancia o el tribunal de cuentas de segunda instancia podrá juzgar el reparo como una infracción administrativa y aplicar alguna de las medidas disciplinarias contempladas en el Estatuto Adminis-

23. Por ejemplo, Tribunal de Cuentas de segunda instancia, sentencia rol 37.732-10, «Contraloría General de la República con Palma, Arturo», 14 de septiembre de 2012; sentencia rol 41.219-11, «Contraloría General de la República con Lapierre, Alfredo», 6 de abril de 2015; sentencia rol 3-2013, "Contraloría General de la República con Tatter, Jorge», 12 de agosto de 2016 y sentencia rol 78-2015, «Contraloría General de la República con Ormazábal, Jorge», 7 de agosto de 2017.

24. Tribunal de Cuentas de segunda instancia, sentencia rol 31.701-06, «Contraloría General de la República con Orrego, Samuel», 2 de julio de 2009; sentencia rol 23-2013, "Contraloría General de la República con Rubio, María Paz», 30 de marzo de 2015 y sentencia rol 53-13, «Contraloría General de la República con Hidalgo, Guillermo», 22 de diciembre de 2015. 
trativo que no importe expiración de funciones, norma que se aplica en la actualidad con relativa frecuencia. ${ }^{25}$

Aquella disposición, a primera vista parece desprovista de razonabilidad, porque hace aplicable una medida disciplinaria como consecuencia de un procedimiento que desde su origen tiene por finalidad determinar la responsabilidad pecuniaria de un sujeto y no su responsabilidad administrativa (Montero, 2015a: 116), pero ella adquiere consistencia si se estima que la infracción de la norma administrativa derivada del procedimiento previo al juicio de cuentas, consistente en un examen de cuentas practicado por el Organismo Contralor o un sumario administrativo, constituye un presupuesto de la responsabilidad patrimonial.

Por su parte, los tribunales ordinarios, en las sentencias condenatorias por los delitos de malversación de caudales públicos y la consecuente condena civil por reparación, realizan un razonamiento sobre la base de los deberes que emanan de la función pública, a partir de lo cual configuran las responsabilidades de los sujetos que administran fondos o bienes fiscales. En ellos se puede apreciar que la responsabilidad civil surge como corolario de la responsabilidad penal y de la infracción de las normas administrativas que rigen el comportamiento de los imputados. ${ }^{26}$

Expresado lo anterior, esto es, que la infracción de la norma que rige el comportamiento del agente administrador de fondos o bienes públicos constituye un elemento fundante de la responsabilidad en comento, cabe preguntarse cuál es el rol específico de esa infracción en la determinación de la responsabilidad.

La doctrina chilena relaciona la transgresión normativa con la culpabilidad, y la ha aplicado principalmente a la responsabilidad civil derivada de accidentes del tránsito o ferroviarios (Aedo, 2014b: 707).

25. Desde la sentencia rol 3-2013, "Contraloría General de la República con Tatter, Jorge», 12 de agosto de 2016 y sentencia rol 63-2013, "Contraloría General de la República con Mitre, Guillermo», 12 de agosto de 2016, en adelante, se aplicaron medidas disciplinarias por una parte y se dejó sin efecto la condena patrimonial por otra, lo que el tribunal llamó «sustitución de la sanción», expresión desafortunada, dado que la misma ley señala que en estos casos no procede condenar pecuniariamente por la naturaleza de los hechos investigados, entonces no hay nada que sustituir.

26. Es así que el Tribunal Oral en lo Penal de Punta Arenas, sentencia RIT 42-2014, «Ministerio Público Fiscalía Local de Porvenir con Atilio Fabián Gallardo Bustamante», 11 de junio de 2015, configuró el delito de peculado cometido por dos funcionarios municipales sobre la base del quebrantamiento de normas especiales que imponen una determinada conducta en el desempeño de su cargo. El mismo razonamiento encontramos en Tribunal Oral en lo Penal de Valparaíso, sentencia RIT 41-2013, «Con Lorenzo Antonio Leiva Tapia», 19 de mayo de 2013; $2^{\circ}$ Juzgado de Letras de Punta Arenas, sentencia rol C-211-2010, "Consejo de Defensa del Estado con Chamorro», 25 de octubre de 2010; Corte de Apelaciones de Rancagua, sentencia rol 17.248, causa 37-2010 (crimen), «Con Jerobaal Elías Cid Cortés. Qte: Benedicto Zúñiga Reyes y Consejo de Defensa del Estado (fraude artículo 239 C.P.)», 21 de julio de 2011; Corte Suprema de la República de Chile, sentencia rol 5.903-2007, "Con Juan Nahuelpi Ramírez; Héctor Alejandro Arellano Peña; Ulises Armando Asenjo Ramírez; María Luisa Chaperón Toro; Rosamel Arturo Palma Torres; Luis Ramírez Berríos; Marcelo Luciano Carrasco Carrasco; Claudio Gómez Musset; María Henríquez Orrego», 1 de septiembre de 2008 . 
El asunto se ha tratado como culpa contra la legalidad o culpa infraccional, a propósito de la culpa del autor frente a la infracción de un deber de cuidado impuesto por el legislador u otra autoridad con potestad normativa (Barros, 2006: 98; Ramos, 2008: 54; Abeliuk, 2014: 267; Pizarro, 2010: 172).

De esta manera, se afirma que cuando la conducta exigida se ha explicitado en reglas formales que señalan cuál es el comportamiento cuidadoso exigido, el solo hecho de que el agente las haya transgredido con su comportamiento es suficiente para considerar que ha existido culpa en su actuación (Corral, 2013: 211).

Igualmente, Alessandri (2005: 128) ha señalado que la apreciación de la conducta del sujeto resulta innecesaria si el daño proviene de una violación de una obligación impuesta por la ley o un reglamento, ya que ello significa que omitió las medidas de prudencia o precaución que una u otras estimaron necesarias para evitar un daño.

Así también, Barros (2006: 143) indica que si el deber se encuentra definido por una norma, al demandante le bastará probar su infracción, porque entiende que la sola contravención expresa la culpabilidad. Rodríguez (1999: 183) va aún más allá al aseverar que la infracción determina la responsabilidad del sujeto.

Por otro lado, algunos autores niegan el hecho de que la violación de la norma determine la existencia de la culpa, por cuanto aseveran que lo que dicha vulneración determina es la antijuridicidad (Molinari, 2004: 107), recogida expresamente en los artículos 1.437 y 2.284 del Código Civil. Dicho elemento consiste en un comportamiento contrario al ordenamiento normativo en su integridad, u objetivamente ilícito. En ese sentido, se ha observado que la infracción contravencional constituye un factor indiciario de antijuridicidad de la responsabilidad civil anexa a la infraccional (Corral, 2013: 115).

La cuestión presenta particular relevancia en la materia que tratamos. Los administradores de bienes públicos tienen normado su comportamiento, de manera que existiendo una infracción a deberes de diligencia establecidos en normas legales o reglamentarias, podría concluirse que son culpables y, por tanto, responsables; o bien que solo tiene lugar una conducta antijurídica, faltando aún la culpabilidad para declararlos responsables.

Ciertamente, la infracción normativa es un elemento fundante de la responsabilidad en estudio y, por tanto, una manifestación de la antijuridicidad de la conducta. ${ }^{27}$

Pero el hecho de que los sujetos que tienen a su cargo bienes públicos tengan normado su comportamiento no significa, en principio, que la infracción del deber de

27. Ello aun cuando parte de la doctrina incluya la ilicitud en la culpabilidad o en el daño, o simplemente niegue la existencia de la antijuridicidad, argumentando que tiene poco sentido práctico construir la culpa y la antijuridicidad como requisitos diferentes, y que en el Código Civil \artículo 2.329囚 esta se asocia al dolo y a la culpa, sin que pueda ser concebida como un elemento aislado dentro de los presupuestos de la responsabilidad (Barros, 2006: 132). Esta negación del elemento antijuridicidad proviene precisamente de la importancia del elemento daño como fundamento de la responsabilidad extracontractual, con indiferencia de la ilicitud (Rodríguez, 1999: 130; Corral, 2013: 111). 
conducta contenido en la normativa especial que rige su actuación importa también su culpabilidad, pues ello pugna con las exigencias de nuestro sistema de responsabilidad que emplea una noción clásica de culpa, y además permitiría considerar como fuente directa de responsabilidad civil o de presunción de la misma cualquier vulneración de una norma concerniente al comportamiento del agente, por general que esta fuese, con prescindencia de la conducta del sujeto, situación que resulta peligrosa dada la abundancia y dispersión de normas en el terreno administrativo (Vergara, 2010: 19). ${ }^{28}$

Esa dispersión es más perceptible y compleja en los cuerpos normativos de rango inferior a la ley, como las circulares, instructivos, decretos, resoluciones y ordenanzas, emanados de las autoridades administrativas centralizadas o descentralizadas con potestades reglamentarias (Cordero, 2010: 21-50).

Con todo, la infracción de la norma puede envolver la culpabilidad en el evento en que la disposición que rige la actuación del agente, ya sea en forma aislada o en relación con otras prescripciones de conducta del mismo, delimite de tal forma la diligencia exigible que no se pueda concluir que, a pesar de la transgresión normativa, el sujeto fue diligente. ${ }^{29}$

Pues bien, en la materia analizada coexisten prescripciones de conducta de distintos niveles de especificidad, entre ellas, normas lo suficientemente precisas en la fijación de algunas funciones que importan deberes de conducta que solo es posible cumplir utilizando un grado especial de diligencia, de modo que la infracción de la norma lleva implícito el descuido del sujeto.

Por ejemplo, el deber de la unidad de obras municipales de dar aprobación a los anteproyectos y proyectos de obras de urbanización y edificación, y otorgar los permisos correspondientes, previa verificación de que estos cumplen con los aspectos a revisar de acuerdo a la Ley General de Urbanismo y Construcciones (artículo 24 numeral 2 letra a) de la Ley 18.695, Orgánica de Municipalidades), o el deber de integrar y consolidar la formulación del presupuesto anual del Servicio de Salud, en el marco de la planificación de la Red Asistencial, respecto del Departamento Subdirección de Recursos Físicos y Financieros (artículo 22 I letra a) del decreto 140 de 2005, que fija el Reglamento Orgánico de los Servicios de Salud).

En estos casos, la ejecución del deber descrito en la norma exige una labor que en sí misma impone la aplicación de un cuidado mayor, asociado a determinadas competencias específicas, ${ }^{30}$ de modo que el incumplimiento del precepto, además de ser una

28. Bermúdez (2014: 54) trata el tema a propósito del pluralismo y heterogeneidad de las fuentes del derecho administrativo. Hay que mencionar además que tal afirmación trasciende del terreno administrativo, puesto que el autor Domínguez (1989: 119) ya había señalado que la culpa contra la legalidad en la actualidad no tiene ninguna legitimidad frente a la frondosidad de la reglamentación legal en que no es posible el conformar todo el actuar a las prescripciones legales y reglamentarias.

29. En tal sentido, el autor Aedo (2014b: 714) sostiene que la sola violación normativa no puede configurar culpa, salvo que la norma construya directamente el estándar.

30. En este caso la culpa es complementada con la impericia, que se presenta en la administración de efectos públicos cuando el sujeto infringe normas técnicas consustanciales a una actividad, sin tener la 
conducta antijurídica del individuo, envuelve también su culpa. El agente solo podrá eximirse de responsabilidad si demuestra que no concurren los demás requisitos exigidos para su configuración, entre los que se cuenta la relación de causalidad. Así, podría eventualmente demostrar que la infracción tuvo lugar por causa de fuerza mayor.

Enseguida, existen deberes prescritos en términos generales que no resultan suficientes para establecer el comportamiento diligente y así arrancar o presumir culpabilidad de su infracción. Para ilustrar lo señalado, puede citarse el Estatuto Administrativo, que en su artículo 61 letra b) impone la obligación de los funcionarios de orientar el desarrollo de sus funciones al cumplimiento de los objetivos de la institución y a la mejor prestación de los servicios que a esta correspondan.

En el ejemplo citado se hace necesario además precisar el deber concreto de conducta para dar por acreditada la culpa del sujeto, caso en el cual debe recurrirse al estándar del artículo 44 del Código Civil, referido al hombre medio. De manera que la transgresión de una norma que impone en términos genéricos un deber de actuación importa antijuridicidad, pero no culpabilidad.

En la práctica, el Tribunal de Cuentas, sin distinguir el grado de especificidad de la obligación contenida en la norma, ha sostenido que la inobservancia de un deber descrito en una norma legal no puede originar en sí mismo culpabilidad si el daño no deviene de una acción u omisión atribuibles a negligencia o descuido, de manera que no puede configurarse la responsabilidad únicamente a partir de la infracción al deber descrito en la norma. ${ }^{31}$

capacidad técnica, habilidad, experiencia o conocimiento exigidos. En la materia, Rosso (2008: 693-715) indica que la culpa es un concepto complejo y abierto, que necesita ser integrado o individualizado a través de otros innumerables términos que particularizan la conducta, como la imprudencia, la negligencia y la impericia.

31. Por ejemplo, los pronunciamientos del Tribunal de Cuentas de segunda instancia: sentencia rol 31.638-06, «Contraloría General de la República con Undurraga, Alberto», 8 de agosto de 2008; sentencia rol 31.701-06, «Contraloría General de la República con Orrego, Samuel», 2 de julio de 2009; sentencia rol 40.362-2011, "Contraloría General de la República con De la Barra, Alejandra», 4 de mayo de 2012; sentencia rol 40.038-2011, "Contraloría General de la República con Morales, Juan», 13 de julio de 2012; sentencia rol 35.211-2009, «Contraloría General de la República con Sequeira, Doris», 24 de agosto de 2012; sentencia rol 44.208-12, "Contraloría General de la República con Pacheco, Fernando», 14 de octubre de 2014; sentencia rol 44.783-12, "Contraloría General de la República con Sánchez, Francisco», 30 de septiembre de 2014; sentencia rol 41.148-11, "Contraloría General de la República con Meza, Gerson», 16 de marzo de 2015; sentencia rol 50-13, «Contraloría General de la República con Troncoso, Jhon», 6 de enero de 2015; sentencia rol 40.359-11, «Contraloría General de la República con Campos, María», 22 de julio de 2015; sentencia rol 51-14, «Contraloría General de la República con Navarrete Héctor», 30 de noviembre de 2015 y sentencia rol 65-13, «Contraloría General de la República con Valdés Luis», 9 de mayo de 2016. En el penúltimo de los fallos mencionados se afirma que el ejercicio de las funciones establecidas en los artículos 23 letra b), 27 y 30 de la Ley 18.695, además de lo previsto en el artículo 103 de la Ley 10.336, supone el despliegue efectivo de facultades de administración de recursos públicos y, en tal sentido, cualquier pago autorizado por los demandados, al margen de las descripciones legales y reglamentarias que los rigen, puede generar un perjuicio que, mediando algún grado de culpa del cuentadante, es susceptible de resarcirse por esta vía. 
Es así que las sentencias aluden a deberes generales como el deber de control jerárquico permanente de las jefaturas, consignado en el artículo 11 de la Ley 18.575, 64 letra a) de la Ley 18.834 y 61 de la Ley $18.883 .{ }^{32}$

Igualmente, los fallos apuntan a deberes más concretos, como el deber de visar los decretos de pago que le asiste a la unidad de Administración y Finanzas Municipal, ${ }^{33}$ o los deberes específicos de los Departamentos de Finanzas y Contabilidad de instituciones de educación superior. ${ }^{34}$ Pero constantemente afirman que la sola transgresión no supone culpabilidad del sujeto, la cual debe, en todo caso, ser acreditada por el demandante. 35

Solo de manera excepcional se ha resuelto que la vulneración de la norma implica una negligente administración del presupuesto público que cuando no se expresa causa conlleva un perjuicio, exigiendo al demandado en tal caso acreditar una causal que justifique la infracción para eximirlo de responsabilidad.

En definitiva, la infracción de la norma es un elemento de la responsabilidad que manifiesta la antijuridicidad, por cuanto las personas que se desempeñan como administradores de bienes o efectos públicos están sujetas a normas reguladoras de su conducta, cuestión que ha aseverado la jurisprudencia de cuentas. Empero, solo en ciertos

32. Tribunal de Cuentas de segunda instancia, sentencia rol 31.701-06, «Contraloría General de la República con Orrego, Samuel», 2 de julio de 2009, o la obligación del administrador municipal como colaborador directo del alcalde en las tareas de coordinación y gestión del municipio (Tribunal de Cuentas de segunda instancia, sentencia rol 51-14, «Contraloría General de la República con Navarrete Héctor», 30 de noviembre de 2015).

33. En el fallo del Tribunal de Cuentas de segunda instancia, sentencia rol 40.038-2011, «Contraloría General de la República con Morales, Juan», 13 de julio de 2012, se señala que la función de visar los decretos de pago del artículo 27 de la Ley 18.695, debe analizarse a la luz de las atribuciones y exigencias del respectivo cargo para establecer un deber de conducta razonablemente exigible, y por ello no puede atribuirse responsabilidad civil a un servidor que, al momento de examinar los antecedentes para la visación del decreto de pago, no le resultó exigible un deber de supervisión que escapaba a lo razonablemente posible, donde el acto que visaba revestía una apariencia de legalidad constatable con mediana diligencia y cuidado.

34. El Tribunal de Cuentas de segunda instancia, en la sentencia rol 35.211-2009, «Contraloría General de la República con Sequeira, Doris», 24 de agosto de 2012, se refiere al artículo 53 del Decreto Universitario 480, de 1983, Reglamento Orgánico de la Universidad de Valparaíso, que establece las funciones para el cargo de jefe del Departamento de Finanzas y del jefe del Departamento de Contabilidad respecto de la dirección superior de la administración y las finanzas universitarias.

35. Por ejemplo, Tribunal de Cuentas de segunda instancia, sentencia rol 33.417-08, «Contraloría General de la República con Añazco, Nancy», 26 de abril de 2012 y sentencia rol 78-2015, «Contraloría General de la República con Ormazábal, Jorge», 7 de agosto de 2017. Dichos procesos tuvieron como fundamento el pago fuera de plazo de las cotizaciones previsionales de los funcionarios, que generó intereses moratorios. El último fallo dispone que la imputación de responsabilidad se funda además en los deberes del jefe de Finanzas, establecidos en el artículo 27 letras b) y c) de la Ley 18.695 y en el artículo 33 del Reglamento de Organización Interna de la municipalidad afectada, en particular el deber de informar trimestralmente al Concejo el detalle mensual de los pasivos acumulados, desglosando las cuentas por pagar por el municipio y las corporaciones municipales, y que, según el tribunal, corrobora la obligación de esa jefatura de velar por el estado de las deudas del patrimonio municipal. 
supuestos la contravención llevará implícita la culpabilidad, y es en aquellos casos en que las reglas determinan en forma específica el deber de conducta diligente, de modo que las regulaciones normativas establecen el estándar de conducta (Aedo, 2015a: 825).

Entonces, para determinar si la transgresión normativa que expresa la antijuridicidad de la conducta envuelve también la culpabilidad del sujeto, o bien requiere esta ser construida de acuerdo al estándar del hombre medio fijado por el legislador civil, es necesario distinguir la naturaleza del precepto infringido, al diferir la normativa en rango y especificidad.

Sin embargo, ello no ha sido reparado por la jurisprudencia, que normalmente trata la infracción como un elemento que solo concurre con la culpabilidad, sin atender a los distintos deberes preexistentes que se estiman infringidos.

\section{Deberes de la función pública que inciden en la responsabilidad en análisis}

Como se ha expuesto, uno de los aspectos a considerar en la configuración de la responsabilidad por el manejo de recursos públicos en la Administración es la infracción de deberes de conducta del agente que maneja tales recursos públicos, y que no son sino la concreción del ejercicio de la función pública.

También se señaló que dado que estos deberes no arrancan de un contrato, sino de un instrumento legal o reglamentario, la obligación de reparar no es de carácter contractual, requisito indispensable para entrar en ese campo de responsabilidad, según se desprende del artículo 1.556 del Código Civil (Ramos, 2008: 17).

Es por ello que resulta necesario examinar los deberes que se suponen infringidos para fundar esta responsabilidad.

En materia de recursos públicos se advierte que el legislador ha desarrollado distintos niveles de especificidad en las normas, y pueden distinguirse deberes establecidos para la Administración en general, otros más concretos concernientes a cada uno de sus estamentos como ministerios, intendencias, gobernaciones y fuerzas armadas, entre otros, que dicen relación con los objetivos y fines del servicio, y otros que tienen por destinatarios específicos a aquellos sujetos que manejan las finanzas públicas, como las normas dirigidas a un determinado jefe de finanzas de alguna repartición.

La exigencia general establecida para la toda Administración en materia de fondos públicos la conforma el deber de observar el principio de legalidad del gasto, que se encuentra consagrado en los artículos 6, 7, 98 y 100 de la Constitución, artículo 2 de la Ley 18.575 y 56 de la Ley 10.336, así como en el Decreto-ley 1.263, de 1975, y en su reglamentación complementaria. Dicho deber impone la obligación de atenerse a las disposiciones que regulan el egreso y la inversión de los fondos públicos, de modo que toda disposición de estos solo se hará cuando la ley expresamente lo autorice, para los efectos que ella prevea, con la fundamentación del interés público que el legislador haya asignado al organismo correspondiente y en la forma que el ordenamiento jurídico exija.

De igual modo, en lo tocante a la ejecución presupuestaria del sector público, que 
comprende a todas las instituciones descritas en el artículo 2 del Decreto-ley 1.263, esta se rige por una ley de presupuestos formulada por un organismo encargado de proponer las asignaciones - denominado Dirección de Presupuestos-, y que contiene una estimación de ingresos y autorización de gastos a los cuales debe sujetarse cada una de las reparticiones públicas anualmente. Por su parte, el presupuesto anual de las municipalidades - que son organismos autónomos en lo tocante a la administración de sus finanzas - se aprueba de acuerdo a la normativa de su propia ley orgánica.

Además, para cada estamento de la Administración se pueden observar normas en las respectivas leyes particulares de cada repartición, que establecen obligaciones destinadas al cumplimiento de sus objetivos y fines propios, y otras normas que imponen deberes a los servidores en razón de los cargos que ostentan, siendo las más importantes aquellas que se refieren a las funciones de los cargos directivos.

Un ejemplo de ello a nivel local es el de las obligaciones impuestas por la Ley Orgánica de Municipalidades al alcalde, quien de acuerdo al artículo 56 tiene la dirección y la administración superior de la corporación edilicia, y también debe ejecutar una serie de funciones de orden financiero, contempladas en el artículo 63 del mismo cuerpo legal.

Además del alcalde, existen otras unidades encargadas de las finanzas con facultades de administración y disposición de bienes municipales cuyas funciones se establecen en diversos apartados de su ley orgánica, y aquellas unidades que tienen la administración de fondos y su custodia, con los deberes asociados de rendir cuenta ante el Ente Superior de Fiscalización (Fernández, 2008: 62).

Sea que se trate de un deber establecido en términos genéricos o específicos, la transgresión de cualquiera de ellos puede dar lugar a la responsabilidad pecuniaria en la medida en que concurran sus restantes requisitos.

Pero los deberes que dicen relación directa con el manejo de recursos públicos conviven con aquellos que rigen la organización administrativa, y la conducta general del agente como ejecutor de la función pública, ${ }^{36} \mathrm{y}$ que inciden con la misma intensidad en la determinación de responsabilidad patrimonial.

Los más característicos que se analizarán emanan de la jerarquía administrativa, que es uno de los principios sobre el cual se estructura la Administración y que ha sido constantemente considerado por el Tribunal de Cuentas para excluir o establecer la responsabilidad. Ello porque la administración de bienes públicos, particularmente el caso de los egresos fiscales, obedece a un proceso complejo de actos administrativos y contables que involucra diversos intervinientes de varios niveles estructurales de una determinada repartición fiscal, e incluso distintos agentes de la Administración del Estado como municipios, ministerios y otros organismos.

El principio de jerarquía administrativa es entendido como el vínculo jurídico que

36. Estas normas se estructuran sobre la base del artículo 3 inciso segundo de la Ley 18.575 que establece los principios que debe observar la Administración del Estado. 
une a órganos o a funcionarios en relación de superior a inferior, ${ }^{37}$ y que supone una estructura piramidal de la Administración, que se encuentra determinada principalmente por el grado que el funcionario tiene asignado.

Este principio se encuentra consagrado en los artículos 7, 11, 17 y 45 de la Ley 18.575 que disponen que los funcionarios de la Administración del Estado estarán afectos a un régimen jerarquizado y disciplinado en cuya virtud deben cumplir fiel y esmeradamente sus obligaciones para con el servicio, y obedecer las órdenes que les imparta el superior, ${ }^{38} \mathrm{y}$ se determina por la organización interna de cada servicio, como por la planta de personal, que es la organización esquemática de los empleos permanentes que conforman su dotación. ${ }^{39}$

De lo anterior se desprende que la jerarquía da lugar a dos deberes fundamentales que se imponen a los individuos que se desempeñan en la Administración: el deber de obediencia por parte del subordinado y el deber de control jerárquico del que ejerce la jefatura asociado a su poder de mando.

Como se verá a continuación, mientras que el deber de obediencia importa para eximir de responsabilidad a quien ha representado una orden, la infracción del deber de control puede arrancar la responsabilidad del sujeto.

El deber de obediencia como emanación del principio de jerarquía administrativa, y contrapartida de la facultad de mando, es un aspecto que puede considerarse en la determinación de la responsabilidad por cuanto tiene sus reglas propias y se manifiesta, para efectos de este estudio, cuando el agente ejecuta un acto en cumplimiento de una orden de la autoridad legítima (Alessandri, 2005: 438) o de su superior jerárquico. El subordinado bien puede ejecutar una orden que le extrañe, mas no aquella que choque con él, a menos que se encuentre sometido a coacción (Mazeaud, Mazeaud y Tunc, 1962: 145).

En estos casos, el funcionario que ejecuta la orden de realizar un desembolso en cumplimiento de su deber de obediencia es tan responsable como el sujeto que da la orden, salvo que manifieste su disconformidad con aquella en razón de ser ilegal el gasto, y represente el acto a la jefatura respectiva.

La representación de una orden expedida por una autoridad legítima se ha tratado como causal de exclusión o exención de responsabilidad, pues impide que esta se configure por falta de presupuestos (Ossa, 2009: 62). Se exige una conducta positiva para eximir de responsabilidad al demandado, encaminada a rechazar el cumplimiento de órdenes emanadas del jefe superior.

37. Dictámenes de la Contraloría General de la República 68.740, de 1967; 15.448, de 1992 y 15.458, de 1996.

38. Ello se relaciona además con la Ley 18.834 que desarrolla los principios en que se funda la carrera funcionaria en sus artículos 3, 5, 9, 32 y 64, como asimismo con el estatuto de funcionarios municipales, Ley 18.883 , según se consigna en sus artículos 58 letras a), f) y g). La jurisprudencia administrativa profundiza dicho principio en los siguientes Dictámenes de la Contraloría General de la República: 35.341, de $1998 ; 6.038 ; 6.039 ; 6.040 ; 6.042 ; 6.233 ; 7.284 ; 7.285$ y 7.318 , todos de 2010 .

39. Dictamen de la Contraloría General de la República 78.994, de 1979. 
Es así que, en el terreno del manejo de los efectos públicos, la Ley 10.336 preceptúa en su artículo 64 que ningún funcionario será relevado de responsabilidad por haber procedido, en virtud de orden de un funcionario superior, al pago, uso o disposición de los fondos o bienes de que sea responsable, salvo que compruebe haber representado por escrito la ilegalidad de la orden recibida. En tal caso, aquel deberá cumplirla, quedando exento de toda responsabilidad, la cual recaerá en el funcionario que ordene el pago o empleo ilegal de dichos bienes.

En similares términos, tanto el estatuto de funcionarios públicos como el de funcionarios municipales prevén en sus artículos 62 y 59, respectivamente, esta excepción al deber de obediencia, pero referida a todas las órdenes impartidas por el superior jerárquico.

Finalmente, la Ley 18.695 señala en el artículo 29 letra c) que es función de la unidad de control representar al alcalde los actos municipales que estime ilegales.

Luego el legislador establece una serie de requisitos para excluir la responsabilidad del funcionario, ${ }^{40}$ de manera que la representación efectuada en los términos establecidos por la ley exime de responsabilidad a quien ejecuta la instrucción insistida, en tanto se trata de un mecanismo basado en la buena fe y en la comprobación de la eficiencia y eficacia en el cumplimiento de los deberes funcionarios, más allá de las órdenes que impartan los superiores jerárquicos. ${ }^{41}$

Es posible estimar que aún sin cumplir con los presupuestos formales exigidos por la ley, si el demandado durante el juicio acredita que ha representado por escrito a su superior el gasto que constituye un perjuicio al patrimonio fiscal, ello constituye fundamento bastante para excluir el elemento de culpabilidad, ya que no puede determinarse una conducta negligente del agente que sea causante del perjuicio.

Sin embargo, la jurisprudencia reciente del Tribunal de Cuentas ha sostenido que la representación del gasto prevista en la ley debe además reunir otras condiciones para que contenga inequívocamente el rechazo al egreso cuya aprobación se requiere al funcionario, en términos tales que no quepa duda de cuáles son los gastos cuya legalidad se objeta, de su origen e ítem presupuestario, así como de los fundamentos de la representación y cualquier otro elemento que permita establecer de manera indudable la actuación administrativa contraria a la ley. ${ }^{42}$

Por consiguiente, la obediencia no exime de responsabilidad patrimonial a menos que el subordinado represente la orden del superior, en los estrictos términos que or-

40. El artículo 29 letra c) de la Ley 18.695, por ejemplo, dispone que «Dicha representación deberá efectuarse dentro de los diez días siguientes a aquel en que la unidad de control haya tomado conocimiento de los actos. Si el alcalde no tomare medidas administrativas con el objeto de enmendar el acto representado, la unidad de control deberá remitir dicha información a la Contraloría General de la República».

41. Tribunal de Cuentas de segunda instancia, sentencia rol 37.144-10, «Contraloría General de la República con Saavedra, Luis», 23 de agosto de 2013.

42. Tribunal de Cuentas de segunda instancia, sentencia rol 47-13, "Contraloría General de la República con Valdivia, Guillermo», 25 de enero de 2016 y sentencia rol 44.872-12, «Contraloría General de la República con Reyes, María», 10 de junio de 2016. 
dena la ley y la jurisprudencia. No obstante, debe considerarse que la misma estructura jerarquizada de la Administración en la realidad importa una intimidación para el subordinado en cuanto a los términos en que presente su objeción y sus consecuencias, por lo cual en ese contexto resulta excesiva la imposición de requisitos adicionales por la jurisprudencia para determinar la suficiencia de la representación.

Ahora bien, en contraposición al deber de obediencia, el superior posee varios atributos entre los que se distinguen la facultad de mando para dar órdenes obligatorias y de fiscalizar el cumplimiento de las obligaciones de los subalternos (Bermúdez, 2014: 176), que no es otra cosa que el deber de control jerárquico.

Como una manifestación del principio de jerarquía, ${ }^{43}$ este deber se impone a las jefaturas y autoridades de los servicios en relación al funcionamiento de los organismos y a la actuación del personal de su dependencia, de acuerdo con el artículo 11 de la Ley 18.575, que indica que dicho control se extenderá tanto a la eficiencia y eficacia en el cumplimiento de los fines y objetivos establecidos como a la legalidad y oportunidad de las actuaciones, y es reconocido también en los artículos 64 letra a) y 61 letra a) de los Estatutos Administrativos para funcionarios públicos y municipales, respectivamente.

Este control se caracteriza por ser permanente, en cuanto no existen actuaciones ajenas o exentas de control, y limitado, en cuanto el superior debe actuar siempre en el ámbito de sus competencias y ejercer el control en los niveles que corresponda, tanto respecto del subordinado, como de la unidad dependiente.

$\mathrm{Al}$ ser un deber de naturaleza administrativa, el Ente Superior de Control en sus dictámenes ha advertido que ciertas conductas constituyen una falta de control jerárquico para efectos de establecer la responsabilidad administrativa del sujeto, ${ }^{44}$ sosteniendo que la obligación de control jerárquico será más estricta en la relación directa que en la relación mediata entre el funcionario infractor y las respectivas jefaturas, de modo tal que se atribuye siempre mayor responsabilidad a la jefatura directa. ${ }^{45}$

No obstante, cuando la máxima autoridad del servicio ha intervenido directamente en la toma de decisiones que condujeron a irregularidades, o no podría sino conocerlas dada su calidad de jefe superior, el deber control jerárquico y la subsecuente responsabilidad se extiende hasta aquel. ${ }^{46}$

Lo precedentemente expuesto no es ajeno al ámbito de la responsabilidad pecuniaria, pues la participación en el hecho lesivo del superior no arranca de un actuar positivo sino de una omisión, manifestada precisamente en no ejercer el control jerárquico. Por ejemplo, en el caso del jefe de servicio que omite ejercer el deber de control sobre las unidades inmediatamente inferiores que realizaron gastos contrarios a los fines del servicio.

Ante esta situación, es fundamental acreditar tanto la negligencia del sujeto como la

43. Dictámenes de la Contraloría General de la República 6.040 y 6.041, de 2010.

44. Por ejemplo, los Dictámenes de la Contraloría General de la República 13.183 de 2006; 2.497 de 2009 y 26.093 de 2010.

45. Dictámenes de la Contraloría General de la República 26.093, de 2010; 4.00o, de 2012 y 96.595, de 2015. 46. Dictamen de la Contraloría General de la República 46.181, de 2007 
relación de causalidad entre la conducta del superior y el daño, en atención a que como se señaló, el cumplimiento del deber de control jerárquico no puede extenderse a todos los niveles. Asimismo, aun cuando exista una relación jerárquica inmediata, tampoco puede responsabilizarse al superior cuando se trata de una actividad encargada al subordinado técnico especializado que comete culpa por impericia.

Por último, la falta de control jerárquico podría sugerir la aplicación de la presunción de responsabilidad por el hecho ajeno, consagrada en el artículo 2.320 del Código Civil, dado que a primera vista concurren los supuestos de tal presunción general, a saber: que el dependiente haya cometido un ilícito civil, y que entre el dependiente y el tercero exista una relación de autoridad o cuidado (Barros, 2006: 176), un vínculo de subordinación y dependencia sin que tenga importancia la causa que origina tal relación (Aedo, 2006: 226). ${ }^{47}$

Pero en la materia no se puede prescindir de la circunstancia de que, si bien el dependiente está subordinado a una determinada jefatura, tiene una serie de deberes que le son propios y que se encuentran directamente relacionados con el manejo de bienes públicos.

Así también debe considerarse que tanto la jefatura como el personal que se desempeña en la unidad a su cargo se encuentran sometidos a un mismo ente administrativo al que sirven, de forma tal que el subordinado no desempeña sus funciones en interés o beneficio del superior, como en las hipótesis de responsabilidad por el hecho ajeno del artículo 2.320 del Código Civil que aluden a vínculos en que no hay ningún sujeto por sobre el tercero civilmente responsable. Es por ello que la jefatura respectiva no puede ser civilmente responsable de los actos de los subordinados, por lo cual debe descartarse la aplicación de la aludida presunción.

En sede de jurisdicción de cuentas se han dado al control jerárquico distintos alcances que dicen relación con la supervisión de las funciones del personal a cargo y del uso de los recursos y demás bienes asignados a una unidad. ${ }^{48}$ Además, se ha afirmado que el control jerárquico se extiende a la legalidad y oportunidad de la actuación del subordinado en cumplimiento de sus funciones. ${ }^{49}$

Pero para fundar la responsabilidad patrimonial del superior, el referido tribunal ha exigido el cuidado del hombre medio en el cumplimiento de este deber. $\mathrm{O}$ sea, un deber de conducta ya establecido normativamente, ha sido especificado a través de la aplicación del criterio del derecho común utilizado para la fijación de deberes de dili-

47. El autor Arturo Alessandri (2005: 223) además menciona como requisito de la responsabilidad por el hecho ajeno que el vínculo de subordinación sea de derecho privado, lo cual no descarta la responsabilidad conforme al derecho público, pero tal afirmación la realiza en torno a la responsabilidad que pudiera tener la Administración por el hecho de sus agentes, sin abordar la hipótesis del funcionario que ejerce una jefatura sobre aquel que le debe obediencia.

48. Tribunal de Cuentas de segunda instancia, sentencia rol 31.701-06, «Contraloría General de la República con Orrego, Samuel», 2 de julio de 2009.

49. Tribunal de Cuentas de segunda instancia, sentencia rol 42.366-2011, "Contraloría General de la República con Van Rysselberghe, Jacqueline», 15 de mayo de 2017. 
gencia. En efecto, se sostiene que tal deber impone estándares de conducta medios a las autoridades y jefaturas llamadas a ejecutarlo, lo cual requiere el despliegue de acciones para alcanzar un adecuado funcionamiento de las unidades respectivas..$^{50}$

Igualmente, y en cuanto a los límites del control, se ha fallado que en el marco de un egreso verificado en cumplimiento de obligaciones que constan en un contrato cuya constatación se encarga al personal especializado, como una obra pública, no procede condenar a las jefaturas por falta de control jerárquico cuando la única forma de advertir la improcedencia de los pagos era a través de la inspección especializada y directa por parte del personal encargado. ${ }^{51}$ En el mismo sentido, se indica que si bien la norma legal que impone el control es amplia, aquel no elimina la correcta ejecución de las funciones de los subordinados..$^{52}$

\section{Algunos aspectos particulares del proceso}

La responsabilidad patrimonial en comento presenta adicionalmente algunos aspectos procesales distintivos.

En primer lugar, la acción para obtener la reparación de los perjuicios originados en el manejo de efectos públicos puede ejercitarse desde luego en sede ordinaria civil y criminal como acción civil de indemnización de perjuicios. Pero, alternativamente, y en ciertos supuestos, puede interponerse en sede jurisdiccional de cuentas, bajo la forma de un reparo, que constituye la demanda en el juicio de cuentas (Ley 10.336, 1952: artículo 107 bis).

Ante un tribunal con competencia en lo penal, la acción civil de indemnización de perjuicios se podrá interponer cuando en el respectivo proceso se persigan determinados delitos contra la función pública, como fraude al Fisco o malversación de caudales públicos, pero solo en el marco de un procedimiento ordinario, regulado en el libro segundo del Código Procesal Penal, que llegue a la etapa de juicio oral en lo penal, única posibilidad para deducir la acción civil de indemnización de perjuicios..$^{53}$

Así, queda excluida esta acción en los procedimientos simplificado y abreviado por disponerlo expresamente los artículos 393 inciso segundo y 412 inciso final del Código Procesal Penal. En ese supuesto, la demanda interpuesta solo puede dirigirse contra los

50. Tribunal de Cuentas de segunda instancia, sentencia rol 32.700-07, «Contraloría General de la República con Guastavino, Luis», 25 de octubre de 2010.

51. Tribunal de Cuentas de segunda instancia, sentencia rol 2.075-06, «Contraloría General de la República con Hernández, Fernando», 25 de agosto de 2015 y sentencia rol 36.718-09, «Contraloría General de la República con Rossat, Verónica», 8 de octubre de 2015.

52. Tribunal de Cuentas de segunda instancia, sentencia rol 44.515-12, «Contraloría General de la República con Zavala, Isaías», 24 de octubre de 2016; sentencia rol 39-2014, «Contraloría General de la República con Muñoz, Luperciano», 7 de noviembre de 2016 y sentencia rol 49-2013, «Contraloría General de la República con Van Rysselberghe, Jacqueline», 27 de mayo de 2017.

53. Ello se desprende del párrafo 2 del título III del libro primero del Código Procesal Penal, en relación con el artículo 261 del mismo cuerpo legal, que regula la actuación del querellante en la audiencia de preparación del juicio oral, facultándolo en la letra d) para deducir demanda civil cuando proceda. 
acusados en el respectivo juicio criminal, de manera que si el ente estatal demandante estima que además les asiste responsabilidad patrimonial a otros sujetos que no tienen la calidad de acusados, tendrá que ocurrir necesariamente a la sede ordinaria civil.

Si se deduce acción civil de indemnización de perjuicios en esta última, sea porque el ilícito es puramente civil o porque constituyendo también un ilícito sancionado con la ley penal no pudo perseguirse en sede criminal por no llegar el proceso al estadio de juicio oral en lo penal, podrá tramitarse como procedimiento de general aplicación en un juicio de Hacienda. El juicio de Hacienda se encuentra regulado en los artículos 748 a 752 del Código de Procedimiento Civil y rige para aquellos asuntos en los cuales tiene interés el Fisco, cuyo conocimiento les corresponde a los tribunales ordinarios de justicia con arreglo a los trámites establecidos para el juicio ordinario de mayor cuantía, con algunas modificaciones.

Finalmente, esta responsabilidad puede hacerse efectiva en sede jurisdiccional administrativa de cuentas mediante un procedimiento contencioso especial regulado en el Título VII de la Ley 10.336, denominado examen y juzgamiento de las cuentas, en el evento de existir un antecedente administrativo que puede consistir en un examen de cuentas practicado por el Organismo de Control o un procedimiento sumarial.

Ahora bien, el examen de cuentas tiene por objeto fiscalizar la percepción de las rentas e inversión de los fondos del Fisco o de las demás entidades sometidas a la fiscalización de la Contraloría General de la República, y comprobar el cumplimiento de las disposiciones legales y reglamentarias que rigen su ingreso y su aplicación o gasto, como también la veracidad y fidelidad de las cuentas, la autenticidad de la documentación y la exactitud de las operaciones aritméticas y de contabilidad (Ley 10.336, 1952: artículo 95). Por su parte, el sumario administrativo es aquel procedimiento que tiene por objeto hacer efectiva la responsabilidad administrativa de un determinado funcionario público. El artículo 129 de la Ley 10.336 indica que, si de tales procesos se dedujere responsabilidad civil del funcionario en relación con los bienes que administra o custodia, sus conclusiones serán consideradas como suficiente examen de cuentas para los efectos de proseguir el juicio de cuentas, denominado examen de cuentas ficto.

Si la responsabilidad se persigue en un procedimiento de cuentas, existe además una limitación temporal para ejercer la acción, debido a que opera la caducidad, entendida como la extinción ipso iure de la facultad de ejercer un derecho por no haberse ejercido dentro de un plazo fatal que la ley establece (Alessandri, 2005: 457). En estos casos el demandante tiene un año para formular reparo en juicio de cuentas, el cual se cuenta desde la recepción de los antecedentes para su examen o desde que el sumario que le da origen se encuentre afinado. En todo caso, la jurisprudencia correspondiente ha entendido que la sola interposición de la demanda impide que se produzca la caducidad del plazo. ${ }^{54}$ Una vez transcurrido dicho plazo, el ente público afectado solo puede

54. Solo a partir del año 2009 el Tribunal de Cuentas de segunda instancia comenzó a considerar la presentación del reparo, y no la notificación de este, para efectos de caducidad, tal como aparece en: sentencia 
perseguir la responsabilidad ante los tribunales ordinarios de justicia.

En cuanto a la legitimación para demandar, hay que distinguir si la acción se ejercita en sede ordinaria civil o penal, o si se interpone reparo en sede administrativa. En todo caso, siempre será un representante del Estado la víctima del hecho lesivo.

Si la responsabilidad se persigue en sede civil o criminal, la Ley Orgánica del Consejo de Defensa del Estado no prevé en forma expresa entre sus atribuciones el ejercicio de la acción civil por los daños ocasionados al Estado. Sin embargo, se entiende que corresponde a este Consejo deducirla, pues a su cargo está el ejercicio de la acción civil que nazca de los delitos en que el mismo haya sostenido la acción penal cuando ello sea conveniente para el interés del Estado, según lo disponen los artículos 2 y 3 de la Ley Orgánica del Consejo de Defensa del Estado, contenida en el Decreto con Fuerza de Ley 1 , de 28 de julio de 1993.

En los juicios de cuentas se encuentra legitimada para deducir la demanda la propia Contraloría General de la República a través del jefe de división o del contralor regional respectivo, aunque en la tramitación del juicio de cuentas asume el rol de parte el fiscal de Contraloría General (Ley 10.336, 1952: artículo 110).

Con respecto a la legitimación pasiva, el sujeto contra el que se dirigirá la acción será lógicamente la persona que tenía atribuciones de cuidado o administración de efectos públicos en las calidades ya analizadas y que con su conducta produjo el daño. En caso de pluralidad de autores, estos pueden ser demandados y condenados solidariamente a la reparación, de acuerdo a lo dispuesto en el artículo 2.317 del Código Civil (Bidart, 1985: 128). Esta solidaridad puede siempre ser alegada y aplicada con independencia de la sede jurisdiccional a través de la cual se accionó.

Desde luego, la solidaridad genera en este ámbito los efectos propios de esta institución, pudiendo el Estado entonces dirigirse contra todos los deudores solidarios conjuntamente o contra cualquiera de ellos a su arbitrio. Solo el cumplimiento total de la obligación la extinguirá respecto de todos los deudores.

Cabe mencionar que, en la normativa pertinente al procedimiento de cuentas, el artículo 103 de la Ley 10.336 indica que, tratándose de reparos en las cuentas de egresos fiscales por gastos variables, según el régimen presupuestario, serán directa y solidariamente responsables los funcionarios que aparezcan firmando el giro. De este modo, se advierte en este caso una suerte de presunción de responsabilidad solidaria de quienes suscriban el documento que contiene el desembolso.

Pero en la materia es necesario considerar que un gasto ilegal es precedido por un

rol 33.371-8, «Contraloría General de la República con Ubilla, Felipe», 20 de marzo de 2009; sentencia rol 42.112-11, «Contraloría General de la República con Santana, Flor», 14 de diciembre de 2012; sentencia rol 30-14, «Contraloría General de la República con Tribiño, René», 2 de marzo de 2015; sentencia rol 47-14, «Contraloría General de la República con Rentería, Claudio», 17 de junio de 2015; sentencia rol 48-14, «Contraloría General de la República con Lobos, Marta», 14 de julio de 2015; sentencia rol 36.718-09, «Contraloría General de la República con Rossat, Verónica», 8 de octubre de 2015 y sentencia rol 3/2015, «Contraloría General de la República con Fernández, José», 30 de mayo de 2016, entre otras. 
proceso contable en el que intervienen varios sujetos que pueden servir en distintos niveles de un determinado estamento de la Administración, con disímiles deberes y jerarquías, de modo que cada uno de ellos se encontraba sujeto a distintas exigencias en razón de su cargo.

Por ello debe examinarse cómo cada uno de los sujetos participó en el respectivo proceso generador del hecho dañino, de modo que la firma no puede por sí misma arrancar la responsabilidad solidaria en todas las hipótesis que pueden presentarse y sus circunstancias particulares.

Por último, corresponde observar que, para el caso de las corporaciones edilicias, la ley deja a criterio de un organismo administrativo la determinación de las consecuencias de la responsabilidad. En efecto, el artículo 54 inciso segundo de la Ley 18.695 prescribe que, para los efectos de determinar la responsabilidad de los funcionarios municipales, la Contraloría podrá fijar, según el grado de intervención que les haya cabido en el hecho, la proporción en que deban concurrir al pago de las obligaciones o aplicar las normas relativas a la responsabilidad solidaria.

\section{Conclusiones}

Del análisis realizado pueden extraerse las siguientes conclusiones:

1. La responsabilidad por el manejo de bienes y fondos públicos en la Administración tiene un tratamiento disperso en la legislación chilena y es totalmente asimilada a la responsabilidad civil extracontractual por los tribunales. Sin embargo, aparecen diversos rasgos distintivos derivados principalmente de la relación entre los sujetos involucrados que son, por una parte, un servidor público que con su conducta causa un daño al patrimonio público, y por la otra, el Estado que se menoscaba patrimonialmente por la acción del servidor.

2. Como el servidor público tiene normado su comportamiento, la responsabilidad de aquel se funda en la infracción de sus deberes, de modo que aun cuando esta se asimile a la responsabilidad civil extracontractual, se estructura con ese atributo propio, cual es la transgresión de un precepto concreto de naturaleza administrativa, que también en la jurisdicción de cuentas se ha ido instalando como requisito configurativo de la responsabilidad.

3. La infracción normativa manifiesta la antijuridicidad de la conducta y puede comprender la culpa del agente cuando de los deberes que rigen su conducta pueda extraerse la diligencia exigible de aquel. En caso contrario, esto es, cuando los deberes no se encuentran suficientemente precisados en el ordenamiento, la infracción normativa no podrá excluir la necesidad de acreditar la culpabilidad conforme al estándar del hombre medio que señala el legislador civil.

4. En el establecimiento de la responsabilidad examinada, el principio de jerarquía y los deberes generales que de él emanan son aspectos relevantes tanto para deter- 
minarla como para excluir al sujeto de la misma, por cuanto existe toda una regulación referida a estos deberes y una consecuente jurisprudencia que la desarrolla.

5. Las vías procesales para obtener la reparación son diversas según cuál sea el tipo de ilícito o si existe una fiscalización por parte el Ente Superior de Control, y todas obedecen a reglas diferentes que se encuentran contempladas en el Código Procesal Penal y en el Código de Procedimiento Civil, o en la Ley 10.336, en caso de formularse reparos. Pero siempre que sean varios los sujetos condenados, deberán responder en forma solidaria sin que interesen cuestiones fundamentales como las exigencias concretas del cargo que ostentaban al concurrir con su conducta al hecho ilícito, o el modo en que lo ejecutaron.

6. Finalmente, se ha podido constatar que no parece ser suficiente la profundidad del tratamiento legal y jurisprudencial en la materia, que demanda tanto la estructura jerarquizada de la Administración como los procedimientos contables complejos que preceden a un egreso, y que hacen necesario diferenciar el tratamiento de los sujetos que concurren al daño, tanto en la determinación de la responsabilidad como en la forma de asumir la consecuente obligación solidaria de reparar al Estado.

\section{Referencias}

Abeliuk, René (2014). Las obligaciones. Tomo I. 6. ${ }^{\wedge}$ ed. Santiago: Legal Publishing, Thomson Reuters.

Aedo, Cristián (2006). Responsabilidad extracontractual. Santiago: Librotecnia.

-. (2015a). «La culpa como criterio de distribución de riesgos sociales ¿Hay en la culpa una infracción al deber de cuidado?». En Álvaro Vidal, Gonzalo Severín y Claudia Mejías (editores), Estudios de Derecho Civil. X Jornadas Nacionales de Derecho Civil, Valparaíso, 2015. Santiago: Thomson Reuters.

-. (2014b). «El concepto normativo de la culpa como criterio de distribución de riesgos. Un análisis jurisprudencial». Revista Chilena de Derecho, 41 (2): 705-728.

Aldunate, Francisco (2009). Manual práctico de Derecho Administrativo. Santiago: Puntolex, Thomson Reuters.

Alessandri, Arturo (2005). De la responsabilidad extracontractual en el Derecho Civil chileno. Santiago: Editorial Jurídica de Chile.

BANFI, Cristián (2015). «El principio del doble efecto en la responsabilidad civil». En Álvaro Vidal, Gonzalo Severín y Claudia Mejías (editores), Estudios de Derecho Civil. X Jornadas Nacionales de Derecho Civil, Valparaíso, 2015. Santiago: Thomson Reuters.

BARros, Enrique (2006). Tratado de responsabilidad extracontractual. Santiago: Editorial Jurídica de Chile.

Bermúdez, Jorge (2014). Derecho Administrativo general. $3{ }^{A}$ ed. Santiago: Legal Publishing. 
BIDART, José (1985). Sujetos de la acción de responsabilidad extracontractual. Santiago: Editorial Jurídica de Chile.

Caldera, Hugo (1981). «Sistema de responsabilidad en la Ley Orgánica de Municipalidades». Revista de Derecho y Jurisprudencia, 78 (3): 99-112.

-. (1991). «Función pública y carrera funcionaria». Revista de Derecho Público, 50: 197-222.

Celis, Gabriel (2010). Curso de Derecho Administrativo. Tomo II. Santiago: Puntolex.

Chadwick, Tomás (2009a). «De la naturaleza jurídica del dolo (I)». Revista de Derecho y Jurisprudencia. Edición Bicentenario: 339-377.

-. (2009b). «De la naturaleza jurídica del dolo (II)». Revista de Derecho y Jurisprudencia. Edición Bicentenario: 379-410.

Contraloría General de la República (1986). La Contraloría General de la República y la administración Municipal. Santiago: Contraloría GeneRAL DE LA REPÚBLICA.

Cordero, Eduardo (2010). «Las normas administrativas y el sistema de fuentes». Revista de Derecho, Universidad Católica del Norte, 17 (1): 21-50.

Corral, Hernán (2013). Lecciones de responsabilidad civil extracontractual. Santiago: Legal Publishing.

Cortell, Robert (200o). «La responsabilidad contable y su enjuiciamiento: principios generales». Revista Española de Control Externo, Tribunal de Cuentas, 2 (4): 105-123.

Domínguez, Ramón (1989). «Aspectos contemporáneos de la responsabilidad civil». Revista de Derecho, Universidad de Concepción, 185: 107-139.

Ducci, Carlos (1971). Responsabilidad civil. Santiago: Editorial Jurídica de Chile.

FERradA, Juan (2012). «La responsabilidad civil de los funcionarios en el Juicio de Cuentas». En Contraloría General de la República. 85 años de vida Institucional (1927-2012). Santiago: Contraloría General de la República.

FERnÁndeZ, José (2008). «Las Municipalidades en relación a la administración financiera del Estado. Responsabilidades». Revista Jurídica del Ministerio Público, 34: 53-75.

Garrido, Mario (2005). Derecho Penal. Parte General. Tomo II. Santiago: Editorial Jurídica de Chile.

GonzÁlez, Olayo (2014). «La responsabilidad contable: su exigencia jurisdiccional». En Memoria del Primer Congreso Internacional del Tribunal de Cuentas. Panamá: Tribunal de Cuentas.

Hanssen, Carlos (2007). La función jurisdiccional de la Contraloría General de la República, el Juicio de Cuentas. Santiago: LexisNexis.

Ivanega, Miriam (2000). «Responsabilidad patrimonial de los funcionarios públicos». En Julio Rodolfo Comadira, Responsabilidad del Estado y del funcionario público. Buenos Aires: Editorial Ciencias de la Administración.

JARA, Jaime (2012). «Caducidad y notificación del reparo en el Juicio de Cuentas». Revista de Derecho Público, 77: 135-162.

Mazeaud, Henri, Léon Mazeaud y André Tunc (1962). Tratado teórico y práctico de 
la responsabilidad civil, delictual y contractual. Traducción de Luis Alcalá-Zamora. Buenos Aires: Ediciones Jurídicas Europa-América.

Meza, Ramón (1997). Manual de Derecho Civil. De las fuentes de las obligaciones. 9. ${ }^{\circledR} \mathrm{ed}$. Santiago: Editorial Jurídica de Chile.

Molinari, Aldo (2004). De la responsabilidad civil al derecho de daños y tutela preventiva civil. Santiago: LexisNexis.

Montero, Cristián (2015a). «Las causales de extinción de la responsabilidad disciplinaria de los funcionarios públicos. Análisis crítico». Revista de Derecho Administrativo Económico, 21: 93-130.

-. (2015b). «La responsabilidad disciplinaria de los funcionarios públicos: un estudio introductorio». Revista de Derecho Público, 82: 111-141.

Ossa, Jaime (2009). Derecho Administrativo sancionador, una aproximación dogmática. Bogotá: Legis.

Pallavicini, Julio (2012). Tratado Jurisprudencial de Derecho Administrativo, Ley $N^{\circ}$ 18.575 interpretada. Santiago: Abeledo Perrot.

Peirano, Jorge (1979). Responsabilidad extracontractual. 2. ${ }^{\wedge}$ ed. Bogotá: Temis.

Pizarro, Carlos (2010). «Daños en la construcción, fuerza mayor y terremotos». Revista de Derecho, Pontificia Universidad Católica de Valparaíso, 34 (1): 161-176.

Politoff, Sergio, Jean Pierre Matus y María Cecilia Ramírez (2004). Lecciones de Derecho Penal chileno. Parte general. Santiago: Editorial Jurídica de Chile.

Ramos, René (2008). De la responsabilidad extracontractual. Santiago: Legal Publishing. Rodríguez, Pablo (1999). Responsabilidad extracontractual. Santiago: Editorial Jurídica de Chile.

Rodríguez, Luis y María Magdalena Ossandón (2011). Delitos contra la función pública. Santiago: Editorial Jurídica de Chile.

Rosso, Gian Franco (2002) «El buen padre de familia como criterio de apreciación de la culpa y su aplicación a la responsabilidad civil cuasidelictual». En Eduardo Court, Derecho de daños. Santiago: Lexis Nexis.

-. (2008) «Negligencia, imprudencia e impericia como conceptos negativos integradores de la culpa. Un intento de conceptualización». En Alejandro Guzmán Brito (editor), Estudios de Derecho Civil III, Jornadas nacionales de Derecho Civil, Valparaíso, 2007 (pp. 693-715). Santiago: Legal Publishing.

Severo, Massimo (1991). Derecho Administrativo. Traducción de Luis Ortega. Madrid: Ministerio para las Administraciones públicas.

Verdugo, Mario (2006). «Efectos vinculantes de los precedentes del Tribunal Constitucional en la actividad de la Contraloría General de la República». Revista del Centro de Estudios Constitucionales, 4 (1): 223-231.

Vergara, Alejandro (2010). El Derecho Administrativo como sistema autónomo: el mito del Código Civil como derecho común. Santiago: Legal Publishing, Abeledo Perrot.

Wollcott, Olenka (2002). La responsabilidad civil de los profesionales. Lima: ARA Editores. 


\section{Sobre la autora}

Ángela Cerda Cattan es abogada, licenciada en Ciencias Jurídicas y Sociales, y Magíster en Derecho: Cultura constitucional y derechos codificados de la Universidad Central de Chile. Su dirección de correo postal es Miraflores 169, oficina 52, Santiago de Chile. Su correo electrónico es angelacerdacattan@gmail.com. 
